\title{
Folk Songs in Regional of North Sulawesi as a Message of Peace to the Community
}

\author{
Rosijanih Arbie $^{1} * \&$ Takko Bandung ${ }^{2}$
}

\author{
${ }^{1}$ Lecturers on Fakultas Ilmu Budaya(FIB) Unsrat, Manado \\ ${ }^{2}$ Cultural Sciences Faculty, Hassanudin University, Makassar \\ *Corresponding Author. Email: rosijaniharbie@unsrat.ac.id
}

\begin{abstract}
Delivery of messages in the information age is currently rife in the community, especially in North Sulawesi which is mediated by mobile phones utilizing SMS (short message service). The vocabulary is shortened arbitrarily so that sometimes it breaks the language structure and confuses the recipient. Indeed, the existence of valuable 'SMS' messages from local culture through folk songs has experienced rapidity in the structure and content of musical arts, especially ethnic vocals. The historical development of folk songs, especially in the North Sulawesi region, has been known since the middle of the great ninth century. What is remembered from the folk songs is termed lagu dolu-dolu(Manado folk songs) which are songs using the Malay language introduced by the Resident of Manado Albert Jacques Frederik Jansen, on August 28, 1859, as a folk song performed by 48 majors, or regional leaders(hukum besar, hukum kedua), which received an umbrella award by the Dutch to the natives, namely Brij khormat (Tambayong, 2007:142-3). Since then, folk songs have transformed into folk songs or popular songs to be sung.
\end{abstract}

Keywords : Lagu-lagu daerah, pesan damai

\section{INTRODUCTION}

Regarding the message of peace for people in a community or region, even the world, it has been going on since time immemorial, especially through the art of music as humans began to interpret the message of 'vocal language' and rhythm in the universe. The chirping of birds during the day, the howling of a dog, the crowing of a rooster and the sound of a cat meowing at night are all messages.

As a sound message, music is an art form that involves the use of sound in an organized manner over a certain continuum of time. Music as a message of nature plays a role in every society, has a large number of styles, and each style is a feature of a geographical area or a historical era [1].

However, whether the 'vocal language' is aimed at fellow birds, dogs, chickens and cats is a sign to convey messages to animals and animals that live in the natural environment together with other creatures, such as humans. This kind of message, of course, will soon be caught by the recipients according to their respective instincts. The content of the message in particular is sometimes only recognized and known to the recipient of the message.

In today's era of information and digitalization, there are still messages that people may have forgotten, especially those messages that are not accessible to phenomenal fulgars and editorials, such as in advertisements, speeches and phenomenal films. There is a special message that wants to be expressed in this paper, namely the message conveyed through folk songs, which have their characteristics in their contents, and are still remembered and able to build enthusiasm and inspire the audience, especially the owners of the songs. The folk songs in question come from an area known as the initials Nyiur Melambai as the others name of North Sulawesi Province.

In the North Sulawesi region, the message known as SMS(Short Message Services) has been around for a long time along with the advent of 
cellphones(HP) to the social media era and the like. The delivery of SMS as a tool of communication is currently increasingly prevalent in the community, especially in the North Sulawesi region, which is mediated by mobile phones. These messages(SMS) have an impact on the language and grammar as well as the message itself because sometimes the recipient does not understand or fail to understand due to the abbreviation. As a result, the negative side associated with arbitrarily abbreviated language vocabulary also destroys the standard language structure and confuses the recipient.

Indeed, there are messages (SMS) in the style of valuable local cultural wisdom, namely via folk songs. Its contents have many values and content that can encourage and strengthen the friendship between communities or individuals. For example, a warning, a deep feeling of longing, uncertainty, sadness, happiness and maybe regret. The message in folks songs which is still popular in North Sulawesi, even though it has been created for a long time, is still preserved and has a strong inspiration for the joints of people's lives, it is considered urgent to study the content of the message. The urgency of this message will be discussed in this paper by highlighting the narration of the texts of the folk songs, namely regional songs, entitled Torang Samua Basudara (Manado Malay), Elur en Kayomba'an (Toulour), Kapia Makalupa (Tountemboan) and Tano-Tanobon (Bolaang Mongondow). These folk songs are beautiful footbridge in establishing friendship and brotherhood among the people of North Sulawesi from various ethnicities and cultures, whenever and wherever they are.

\subsection{At a Glance About Four Folk Songs in Regional North Sulawesi}

The song Torang Samua Basudara created by Rama Aipama has not received much attention and in-depth study. In the author's search, songs that have been popular since the era of the Governor of North Sulawesi region, E.E. Mangindaan (19952000) and helped popularize the idiom of local wisdom with the title Torang Samua Basudara as the embodiment of the term Bohusami(short names of ethnic groups) has hypnotized the people of North Sulawesi and even the archipelago in general.

Remembering E.E. Mangindaan (78), a son from Minahasa (Toutemboan) born in Aceh(Sumatra) and married to a Minahasa daughter Adelina Tumbuan born in Gorontalo(Sulawesi), makes it easier for Governor Lape to carry out the geographical and biological diversity background (as he is called his short name and is very popular with his words as a peaceful campaign of human solidarity: Enjoy, Yes!) in practising life: Torang Samua Basudara(We are brotherhood).
The song is presented in Manado Malay entitled Torang Samua Basudara, composer of the late Rama Aiphama (1956-2020) born in Gorontalo (singer who became hits with recycled pop songs genre such as keroncong Dinda Bestari), Elur en Kayombaan (Toulour), Kapia Makalupa (Tountemboan), Tano-Tanobon (Bolaang Mongondow).

\subsubsection{Lyrics by Rama Aiphama Torang Samua Basudara}

Suda so dari dulu/ Sudah sejak dahulu

kitorang memang baku sayang/Kami saling menyayangi

opa deng oma so kase conto/Kakek dan nenek sudah member teladan

sampe tua baku sayang/Hingga tua nanti saling menyayangi

Ref: :

Uti so kaweng deng keke/Laki-laki asal Gorontalomenikah dengan perempuan asal Minahasa

Nou so kaweng deng ungke/Perempuan asal Gorontalo menikah dengan laki-laki-asal Sanger

Kitorang jadi basudara/Kami telah menjadi bersaudara

satu rasa rica-rica deng dabu-dabu/ Sudah menjadi satu dalam persaudaraan

seperti- rasanya masakan asal Manado -rica-rica dan sambel

Manado deng Gorontalo/ Manado dan Gorontalo

Kitorang baku sayang/Kita saling menyayangi

Sanger deng Bolaang Mongondow/Nama kabupaten di Sulut

Kitorang samua basudara/Kita semua bersaudara

Cinta torang baku cinta/ Saling mengasihi

Sayang torang baku sayang/Saling menyayangi

Karna torang memang satu/Karena kita semua bersaudara

Sulawesi Utara/Propinsi Sulawesi Utara

Below the song lyiric are not song but read like poetry:

"Ya Tuhan Kami

Tuntutlah pemimpin dan bangsa kami ke jalan yang benar

Wahai saudaraku dari sabang sampai Merauke

Hentikan pertikaian dan permusuhan 
Alangkah indahnya hidup berdampingan."

(Oh Lord,

Lead our leaders and our nation to the right path

O my brother from Sabang to Merauke

Stop the fighting and hostility

How beautiful it is to live side by side).

In this folk song Torang Samua Basudara created by Rama Aiphama, the lyrics can be interpreted as a message of peace in the brotherhood of mankind as at the end of the refrain:

Torang samua baku sayang ha hal Kita semua saling menyayangi

Torang samua basudara/ Kita semua bersaudara.

\subsubsection{Lyrics of Elu ren Kayom'baan/ Ampuruk}

Ampuruk ing kuntung pa rege regesan

Maka tembo-tembomai inataran

Kasale en ka aruyen wo kalelo

Tumembo mai ing kayom'baan

Ref.

Kami mengalei ...e..karia ...e...katuari

Se cita'mbaya an do'on tayasa

Ma'esa e nate wo membere-bere na

Elure en kayom 'baan yasa.

\subsubsection{Lyrics of Kapia Makalupa}

Kapia makalupa

Onete tanda mata

Onete tanda mata

Onete tona tantute

Suapa ika neyane sene

Mulia sewawon tana

Mapi pihoto onde

Kapia makalupa

Anyalos mayanto onde

Meken marau hundu-hunduan.

(Live in peace

Make peace with friends

Don't forget

Dear all friends
Even though it's far, don't forget).

\section{RESEARCH METHOD}

By utilizing many literary and cultural theories that have been reviewed above (introduction) and in the following discussion, methods and approaches as well as analysis of folk songs lyrics (texts) from North Sulawesi, in particular, in this study is carried out as concisely as possible so that the message on the meaning of the code language and culture in these folk songs can be understood easily (see, Teeuw, [2]; Junus, [3]; Fokemma, Kunne Ibsch, [4]; Rumengan, [5]; Danesi, [1]; Barthes, [6]; Ratna Kutha, [7].

\subsection{Analytical Approach}

To analyze the lyrics in some folks songs cannot be separated from interpreting the sound (vocals) musically. In a sense, the lyrics in the rhythm of folks songs are imaginary images...which believe that it is the denotative structure of musical language' that is adjective, every mode of signification that explains the 'encoded or perceived expression' in all the tempers of all feelings [6].

The lyrics of folk songs, Torang Samua Basudara, Elur Eng Kayo'mba'an, Kapia Makalupa and Tano-Tanobon are songs that have cultural meanings or codes that can be viewed in terms of their content. To give full meaning to a song text (lyric), it is necessary to analyze its intrinsic structure, its relationship with its historical framework, and its socio-cultural framework.

According to people's narratives about the development of art in general in Indonesian society, a review of the cultural and social context gives various features of the variety of arts that occur because of the layers of culture that accumulate over time and have different functions in different human groups. different [8].

Returning to the intrinsic meaning is intended as a message and cultural code from the speaker community or the creator of song lyrics as a literary work, by itself can change the orientation of its intrinsic meaning into an extrinsic cultural code. According to A. Teeuw: "the process of reading, namely giving meaning to a certain text (lyric), which we choose, or which is forced on us (in teaching, for example) is a process that requires knowledge of a fairly complex code system. , complex and diverse. The first code that we must master if we want to be able to give meaning to a particular text is the language code used in that text" [2].

The phenomenon of interpreting through a classical approach to the intrinsic and extrinsic language code of literary works [9] can occur because the lyrics (song text) as messages and cultural codes always reflect the society, the state of 
the community so that the socio-cultural influence of the community is always attached to the results. the work of an author, poet and songwriter. This background can always describe the aesthetic reception (literary reception) of the community for its cultural messages and codes in the literacy response. Literary reception (aesthetic reception) as stated by this theory that literary reception is how the reader gives meaning to the literary work he reads so that he can give a reaction or response to it, both passively and actively [3].

These songs were analyzed based on the content analysis method which consists of two kinds; namely latent content and communication content. Latent content is the content contained in documents and manuscripts, while the content of the communication is the message contained as a result of the communication that occurs. Latent content is the content as intended by the lyricist (song), while the content of the communication is the content as manifested in the relationship between the script and the intended consumer.

The basis for implementing the content analysis method as a qualitative method is interpretation, which pays attention to the content of the message (language code and aesthetic reception). The way, the researcher emphasizes how the meaning of the communication content, interprets the contents of the symbolic interactions that occur in communication events. For example, the author's writing style in literary works, words, sentences, paragraphs, room volume, writing time and so on [7]

In connection with the study of the seven songs above, the research was conducted by interpreting the contents of the text as a whole to reveal the cultural meanings reflected in the songs. In addition, songs which are one of the works like other literary works also have many dimensions, many aspects, and elements contained in the text, as said by Nyoman Kutha Ratna [7].

As a communication content analysis, a literary text (via folk songs lyrics) is the product of at least two overlapping systems: the linguistic system and the literary system that excels the literary system. Therefore, Lotman concludes that literature, like art in general, is a second modelling system. Thus, the literary system is supralingual. The recipient of a language message must know the linguistic (cultural) code to interpret the message. So, readers of literary texts (through folk songs lyrics) must know the literary code, in addition to the language code. The definition of artistic text cannot be complete without additional classification concerning the relationship between sender and receiver [4]

\subsection{Some Folk Songs and Translations in Indonesian and Analysis Results}

Based on some methods, approaches and text analysis (folks songs lyrics), the results of the following analysis present the text content (lyrics) of Minahasa folk songs -- what is the latent content and communication content in all systems and linguistic and cultural codes in the lyrics The song in question -- becomes the object of research and its translation into Indonesian (italics) and is accompanied by analysis results concerning cultural messages for the Minahasa community in particular and the North Sulawesi community in general.

Elur en Kayo'mba'an (Damai Selamanya)

Am puruk ing kuntung pa rege-regesan

Makatemboi inataran

Kasale'en kaaruyen wo kalelon

Tumbomai ing kayo'mba'an

Ref.

We alei e... karia e... katuari

As much as 'mbaya an do'ong ta ya'sa

Maesa e nate wo membe-berenan

Eluren Ngkayo'mba'an ya'sa.

\section{(Terjemahan Indonesia):}

Di puncak gunung dikala angin bertiup sepoi

lembah dataran terhampar nan begitu indah begitu mengharukan dan menyejukkan hati seperti memandang jagad raya dari tempat yang begitu tinggi

Kami sangat berharap kepada teman-teman dan sanak saudara yang sekarang kita semua berada di kampung tercinta

agar senantiasa dapat menyatukan hati dan saling kasih-

mengasihi/memperhatikan/ gotong-royong sehingga damailah dunia ini selamanya).

In English version is: blows

On the top of the mountain when the wind

the valley of the plains spreads out so beautiful'

so touching and heartwarming

like looking at the universe from such a high place'

We sincerely hope to our friends and relatives'

which now we are all in our beloved village' so that you can always unite your heart and mutual love/caring for/gotong royong' so that the peace of this world forever.

The song Elur en Kayo'mba'an describes the beauty and panorama of the universe that lies on the Minahasa plains, such as the mountains, namely 
Lokon, Soputan and Dua Saudara. An active mountain emitting dust and hot lava containing sulfur is Mount Lokon, located in Tomohon City. Situations and conditions like this are very moving and soothing for the Minahasa people, especially including the threat of an active volcano such as Lokon, if it erupts or releases lava and dust, it will spread to the city of Manado and the entire North Sulawesi region.

Therefore, the natural conditions of the Minahasa area encourage the community to work together, help each other, baku-baku (mutual) love as shown in the mapalus tradition and love one another (maleos-leosan) or baku-baku bae (love each other).

The message conveyed in this song suggests to the Minahasa community to always protect the universe as a gift from God Almighty (Empung Kasuruan Wangko) and to love each other. Thus, the Minahasa people will live in peace on earth forever. The contents of this song contain didactic messages, suggestions and warnings for Minahasa people in particular and the public in general.

Broadly speaking, the lyrical message in the code of language and culture of the Minahasa ethnic group can be summarized in the Minahasa leluri

(legacy) message regarding Si Tou Timou Tumo Tou (ST4), which means humans live to support other humans (Sondakh, [10]; Moningka, et al, [11].

The song Torang Samua Basudara, contains a message of peace because all human beings who live are brothers. The song Elur en Kayomba'an implies a hidden message through a text narrative that is a warning to audiences everywhere in the world to always live in harmony and peace between fellow human beings.

Unlike the song Kapia Makalupa, which transparently conveys a message, it is a suggestion that life in the world must be at peace with friends fellows or anyone - even though they are separated by distance and place. The song Tano-Tanobon expresses a message of peace that is advised to anyone to always listen to the advice of parents, who are well executed and those who are considered inappropriate are buried in the heart so that they will not disappoint others when expressed and in the end, they will live happily.

According to ethnolmusicologist, Prof. Dr. Perry Rumengan M.Sn in his book Hubungan Fungsional: Struktur Musikal - Aspek Ekstramusikal Musik Vokal Etnik Minahasa(Volume II): "The language of vocal music has shown one step higher and deeper than other languages in expressing soul expression. The soul here is not only the soul of the composer but also the soul and the condition of the universe and all its contents", [5].
The contents intended in the folk songs studied include messages of warning, longing, uncertainty, sadness, happiness and peace. The message in LLD, although it has been created for a long time, is still preserved and strongly inspires the joints of social life, especially in the structure of North Sulawesi society which has ethnic and cultural diversity.

The urgency of 'vocal ethnic' messages in folk songs which will be discussed in this paper and by highlighting the narration or lyrics of folk songs in North Sulawesi, in particular: Torang Samua Basudara (Malay Manado), Elur en Kayomba'an (Toulour), Kapia Makalupa (Tountemboan) and Tano Tano Bon (Bolaang Mongondow). These are folks songs still popular and have become a beautiful footbridge in establishing relationships for the depth of content and messages between the people of North Sulawesi wherever they are.

The song Torang Samua Basudara, contains a message of peace because all people from various ethnicities and cultures still live in brotherhood. The song Elur en Kayomba'an also implies a hidden message through its lyrical narrative which is a warning to audiences everywhere in the world to always live in harmony and peace among human beings.

Unlike the song Kapia Makalupa, which transparently conveys a message, it is a suggestion that life in the world must be at peace with friends fellows or anyone - even though they are separated by distance and place. The song tano tano bon expresses a message of peace that is advice to anyone to always listen to the advice of parents, those who are well executed and those who are considered inappropriate are buried in the heart so that they will not disappoint others when expressed and in the end, they will live happily.

Folk songs that are presented in the regional language have factually played a positive active role in developing the potential of language speakers in North Sulawesi as outlined through the narration of the text of the folk songs.

It is in the text of folk songs lyrics from various cultural backgrounds of the speakers that the message of a culture of harmony and peace is stored which have become an adhesive tool for the community as users of "ethnic vocal language" with different origins as a unifying medium. In addition, the lyrics and even the folk songs rhythms studied can provide mutual understanding and understanding of its meaning. Thus, a culture of togetherness or friendship was created between the members of the community in North Sulawesi which until now remains conducive and peaceful with the motto of Torang Samua Basudara. 


\section{CONCLUSION}

The folk songs which is presented in local languages factually has played a positive active role in developing the potential of language speakers in North Sulawesi which is expressed through the narration of the text of regional songs. It is in these texts that the message of a 'peaceful' culture is stored which have become an adhesive tool for the community as users of different regional languages as a unifying medium. In addition, they can understand each other and understand their meaning to create a culture of togetherness or friendship among the people of North Sulawesi which until now is conducive and peaceful with the motto of Torang Saтиa Basudara.

The general conclusion on the analysis of the message of peace in folk songs can be drawn in the scientific speech of the late Dr Dr.(HC) SH. Sarundajang(1945-2021) [12], Governor of North Sulawesi (2005-2015), with his services in mediating the Maluku (Ambon) and North Maluku SARA(ethnic, religion, race) conflicts who have heeded the history of socio-cultural knowledge at UIN Maulana Ibrahim Malang as an award-giving him an honoris causa (HC) to him through his scientific speech entitled Kepemimpinan dalam Masyarakat Majemuk(2012).

The conclusion that is meant as a message of peace taken from this scientific speech is quoted as follows:

"Dear guests,

The long history of the search for national identity (read: nation, ed.) itself was born from an intellectual debate that rarely stops until now: Is Indonesia or Indonesianness a completely new entity whose roots have sprouted and been 'discovered' from the very beginning. 20th century, or a mere continuation of precolonial states such as Majapahit, Srivijaya and Mataram?"

And the most emphatic conclusion from that scholarly speech:

"I think, if a spirit of mutual trust is built between formal and informal leaders, synergistic cooperation will naturally be established in caring for and managing diversity. Through the spirit of mutual trust and cooperation, it is hoped that various phenomena of conflict, violence, and anarchism in the name of original identity (religion, class, ethnicity, taste, region) will decrease by themselves. Because one of the important factors behind the rise of primordial conflicts and tensions is rooted in the low level of trust in our society in state institutions, government institutions, including leaders and law enforcement.

Thus, messages of peace rooted in the lyrics of folk songs through analysis of language and cultural codes are something that remains urgent and continuous to be done as a sign that the recalling culture becomes a potential that must be taken into account in subsequent in-depth studies and takes into account the educative, communicative, integrative, emancipatory and transformative processes of a language and cultural code in the social context of society [13].

\section{REFERENCES}

[1] Danesi, Marcel. (2010). Pesan, Tanda dan Makna: Buku Teks Dasar Mengenai Semiotika dan Teori Komunikasi. Yogyakarta: Jalasutra

[2] Teeuw. A. 1983. Membaca dan Menilai Sastra. Gramedia: Jakarta.

[3] Junus, Umar. 1985. Resepsi Sastra: Sebuah Pengantar. Gramedia: Jakarta.

[4] Fokkema, D.W.; Kunne-Ibsch Elrud. 1998. Teori Sastra Abad Kedua Puluh. Gramedia: Jakarta.

[5] Rumengan, Perry, DR. M.Sn. 2010. Hubungan Fungsional:Struktur Musikal -

[6] Barthes, Roland. 2010. Imaji/Musik/Teks. Jalasutra: Yogyakarta.

[7] Ratna Kutha, Nyoman, Prof. Dr. SU. 2010. Metode Penelitian Kajian Budaya dan Ilmu Sosial Humaniora Pada Umumnya. Pustaka Pelajar: Yogyakarta.

[8] Sedyawati, Edi \& Damono, Sapardi Djoko. 1983. Seni dalam Masyarakat Indonesia: Bunga Rampai. Gramedia: Jakarta.

[9] Wellek, Rene; Warren, Austin. 1989. Teori Kesusastraan: Gramedia: Jakarta.

[10] Sondakh, A.J. 2005. Si Tou Timo Tumo Tou. Sinar Harapan: Jakarta.

[11] Moningka, B.,dkk(Editor). 1996. Manusia di Panggung Sumekola:

[12] Sarundajang, S.H. Dr.DR(HC). 2012. Kepemimpinan dalam Masyarakat Majemuk. UIN Maulana Malik Ibrahim: Malang.

[13] Ointoe, Reiner Emyot. editor,dkk). 1996. Bolaang Mongondow: Etnik, Budaya dan Perubahan. Yayasan Bogani Karya \& Pemda Bolmong: Manado. 